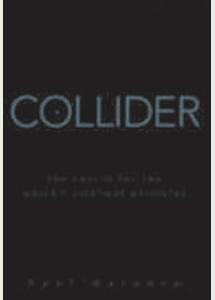

From mini black holes to the origin of mass, the science behind the Large Hadron Collider (LHC) at CERN, Europe's particle-physics laboratory near Geneva, Switzerland, is explored in two recent books. In Collider (Wiley, 2009), physicist Paul Halpern describes how the extreme energies of the LHC will unveil the basic building blocks of the Universe. He explains how the particle accelerator works, how and why it was built and what exciting results it may generate. And he reassures readers that media reports of the machine's ability to create dangerous miniature black holes are unfounded.

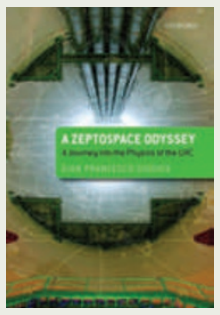

In A Zeptospace Odyssey (Oxford University Press, 2009), theoretical physicist Gian Francesco Giudice also relates the history and physics of the LHC, placing it into a broad context. As well as highlighting the theories that may be challenged by the groundbreaking experiment, including supersymmetry and string theory, he anticipates the intellectual revolution that it may trigger.

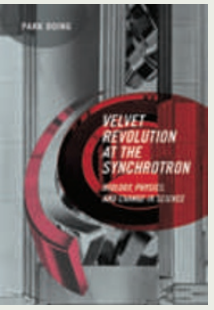

A more widely used type of accelerator is the subject of Velvet Revolution at the Synchrotron (MIT Press, 2009). Sociologist Park Doing examines how biological experiments, such as protein crystallography, have gradually taken over from physical-science studies at synchrotron facilities. Although the machine is a product of the particlephysics work of the Second World War, as an intense $X$-ray source it is frequently used to analyse the structures of proteins and complex molecules. Doing argues that this research switch came about through a series of alternating periods of assertion and resistance, rather than being driven from the top or bottom.

\title{
Body image in Ancient Egypt
}

\section{Body Parts: Ancient Egyptian Fragments and Amulets \\ Brooklyn Museum, New York \\ Until 2 October 2011}

Queen Nefertiti had flat feet. The chief wife of King Akhenaten, who ruled Egypt in the mid-fourteenth century $\mathrm{BC}$, she is known as a long-necked beauty from her bust in Berlin's Neues Museum. But it is her life-sized, long-toed feet that are exhibited at New York's Brooklyn Museum, depicted on a chunk of pink limestone found in the ancient Egyptian city of Hermopolis. The relief, dated to about $1352 \mathrm{BC}$, is one of the first examples of accurate foot anatomy in Egyptian art.

Other representations of body fragments displayed in this small yet delightful exhibition, Body Parts, include arms, hands, eyes, an ear, a beard, a backbone and a heart. The pieces have been assembled by curator Yekaterina Barbash from artefacts stashed in the museum's store rooms, never previously put on show because many are broken.

"When I looked at these fragments, I became aware of details I don't usually notice when viewing a complete sculpture," Barbash says. "I decided that it would be interesting to focus the attention of viewers on just one body part, so that they notice details of modelling, symbolism and workmanship."

For example, a slick of embalming resin is evident between the two fingers of an amulet fashioned from obsidian, a black volcanic glass. Dating from 332 вC, it would have been placed on a mummy as a protective charm and was used to close the incision through which internal organs had been removed before mummification.

A tiny wooden arm, the size of a Barbie doll's, ends in a clenched fist that once held a sceptre, suggesting that it belonged to a statuette of a man, most probably from the third

millennium BC. A braided and curved bronze beard from the mid-seventh century $\mathrm{BC}$ is associated with Osiris, the god of the underworld, and is inlaid with dark-blue glass to represent lapis lazuli, a semi-precious stone from which divine hair was said to have been made. A small obsidian amulet from the same period, shaped like a set of lungs attached to a windpipe, is also a hieroglyph used in the words 'to unite' - a testament to the importance of a unified corpse on its journey in the afterlife.

The Egyptians "really strove to keep the body intact in its most ideal form", says Barbash. However, Egyptian mortuary texts associate different body parts with a specific deity: for example, the lips are associated with Anubis, the jackal-headed god of mummification, and the neck with Isis, patron of women.

Although Egyptian artists emphasized perfection - Nefertiti's flat feet are an ideal, rather than an accurate, model - they also expressed respect for atypical forms such as dwarfism, a syndrome that they linked with gods who protected women during pregnancy and childbirth. Dwarfism is common in Egyptian art, and on display is a granite statue of a short-legged scribe dated to between the first century BC and the first century AD. Nearby is a small wooden figure (1539-1075 BC) with a bowed head and severe curvature of the spine. The fact that sages taught people to be accepting of those with disabilities is shown by a wisdom text from the Ramesside period (1295-1069 вс, named after the 11 kings

Egyptian art and anatomical accuracy went hand in hand.

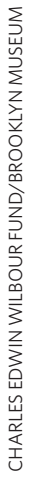

